prevent acute tubular necrosis by reducing vasospasm after reperfusion. Other renal vasodilators, particularly calcium channel blocking drugs, have been shown to reduce delayed function. It seems that the maintenance of renal blood flow after revascularisation is important for early graft function.

1 Varghese Z, Scoble JE, Chan MK, et al. Parathyroid hormone as a causative factor of primary non-function in renal transplants. BMf 1988;296:393.
2 Brown RC, Aston JP, Weeks I, Woodhead JS. Circulating intact parathyroid hormone measured by a two-site immunochemiluminometric assay. $f \mathrm{Clin}$ Endocrinol Metab 1987;65:407-14.

3 Charbon GA, Hulstaert PF. Augmentation of arterial hepatic and renal blood flow by extracted and synthetic parathyroid hormone. Endocrinology 1974;95: $621-6$

4 Ellison DH, McCarron DA. Structural prerequisites for the hypotensive action of parathyroid hormone. Am $\mathcal{Y}$ Physiol 1984;246:F551-6.

5 Pang PKT, Yang MCM, Keutman HT, Kenny AD. Structure activity relationship of parathyroid hormone: separation of the hypotensive and the hypercalcemic properties. Endocrinology 1983;112:284-9.

(Accepted 18 April 1991)
Departments of Medicine, Nephrology, and Medical Statistics, University Hospital Nijmegen, Nijmegen, The Netherlands

L A M Frenken, $M D$, internist

H J J van Lier, MSC, statistics consultant R A P Koene, MD, professor of nephrology

Department of Medicine, St Joseph Hospital, Veldhoven, The Netherlands

PG G Gerlag, MD, internist

Hospital De Gelderse

Vallei, Wageningen, The

Netherlands

$M$ den Hartog, MD, internist

Correspondence to:

Dr Frenken.

BMF 1991;303:288

\section{Assessment of pain after subcutaneous injection of erythropoietin in patients receiving haemodialysis}

\author{
L A $M$ Frenken, $\mathrm{H} J \mathrm{~J}$ van Lier, \\ P G G Gerlag, M den Hartog, R A P Koene
}

Intravenous recombinant human erythropoietin is effective for treating the anaemia of chronic renal failure. ${ }^{12}$ Subcutaneous erythropoietin is also effective. Moreover, it seems that the dosage requirements for subcutaneous administration may be lower than those of intravenous maintenance therapy. ${ }^{4}$

Subcutaneous administration is a convenient way of giving erythropoietin, particularly in predialysis patients and patients receiving peritoneal dialysis. Self administration at home is feasible. However, after subcutaneous injection of Eprex (Cilag, Belgium) several of our patients reported unexpected pain at the injection site, which occasionally precluded self administration.

We report the results of a double blind, placebo controlled, randomised crossover study, designed to assess differences between pain experienced after subcutaneous injection of one of two different erythropoietin preparations or saline $0.9 \%$.

\section{Patients, methods, and results}

All adult patients regularly receiving subcutaneous erythropoietin in two haemodialysis centres $(n=32)$ were invited to participate in the study. Two brands of erythropoietin were tested: Eprex (aqueous solution of $1 \mathrm{ml}$ containing $2000 \mathrm{U} / \mathrm{ml}$ erythropoietin (epoetin alpha) and $2.5 \mathrm{mg} / \mathrm{ml}$ human serum albumin in a citrate buffer) and Recormon (2000 U erythropoietin (epoetin beta) as a lyophilisate, then made up to $1 \mathrm{ml}$ with water: Boehringer Mannheim, The Netherlands). Saline $0.9 \%$ (Braun Melsungen, Germany) served as a placebo and control. Since in each of the centres all patients had been receiving either Eprex or Recormon they had not had the opportunity to compare both preparations with regard to pain. The solutions were equilibrated at room temperature before injection.

Percentage pain scores on visual analogue scale and patient's response on verbal descriptive pain scale after subcutaneous injection of Eprex, Recormon, or saline 0.9\%

\begin{tabular}{|c|c|c|c|}
\hline & Eprex & Recormon & Saline \\
\hline $\begin{array}{l}\text { Visual analogue scores (\%): } \\
\text { Median (second and third quartiles) } \\
\text { Range }\end{array}$ & $\begin{array}{c}35(13,51)^{\star} \\
0-90\end{array}$ & $\begin{array}{c}0(0-1) \\
0-17\end{array}$ & $\begin{array}{c}0(0,7) \\
0-33\end{array}$ \\
\hline $\begin{array}{l}\text { Verbal descriptive scale: } \\
\text { No with very mild or no pain } \\
\text { No with mild to very severe pain }\end{array}$ & $\begin{array}{l}10^{\star} \\
22\end{array}$ & $\begin{array}{r}31 \\
1\end{array}$ & $\begin{array}{r}26 \\
6\end{array}$ \\
\hline
\end{tabular}

At intervals of one hour the $1 \mathrm{ml}$ injections were given subcutaneously in the outer part of the upper arm by an experienced nurse. The sequence of the injections was randomised and blinded for both patient and nurse.

A visual analogue scale with no divisions and a six point verbal descriptive scale were used by the patients to define grades of pain after each injection. ${ }^{5}$ The end points of the $15 \mathrm{~cm}$ vertical line on the visual scale were "no pain at all" and "pain as bad as it could be." The horizontal verbal descriptive scale offered alternatives ranging from "no pain" to "very severe pain." The table shows that the median percentage score on the visual scale was higher after injection of Eprex than after injection of Recormon or saline. The proportion of patients having had very mild or no pain on the verbal scale was low with Eprex $(0 \cdot 31,95 \%$ confidence interval $0 \cdot 16$ to $0 \cdot 50$ ) compared with Recormon (0.97, 0.84 to 0.99$)$ or saline $(0.81,0.68$ to 0.95$)$. There was no significant difference between the scores for Recormon and saline.

In a separate questionnaire the patients were asked which injection was most painful. Five patients had felt no pain after each of the three injections. Twenty six of the remaining 27 patients indicated Eprex, and one indicated saline.

There were no differences in pain scores between patients from the two haemodialysis centres if they were classified according to the regular use of Eprex or Recormon.

\section{Comment}

The results show that pain after subcutaneous injection is typically associated with Eprex. The pain was usually described as burning or itching and was different from the pain occasionally felt after saline or Recormon. In most patients the pain had disappeared after 10 minutes.

The absence of pain after subcutaneous injection of Recormon suggests that the inactive ingredients of the formulation are the cause of the pain. Further study is needed to elucidate whether the citrate buffer or perhaps human serum albumin in the Eprex solution is involved in this troublesome phenomenon.

We thank the patients and the nursing staff in the participating haemodialysis wards for their cooperation and Ms C Pans for her skilful assistance.

1 Eschbach JW, Egrie JC, Downing MR, Browne JK, Adamson JW. Correction of the anemia of end-stage renal disease with recombinant human erythropoietin. Results of a combined phase I and II clinical trial. $N$ Engl f Med 1987;316:73-8.

2 Winearls CG, Oliver DO, Pippard MJ, Reid C, Downing MR, Cotes PM. Effec of human erythropoietin derived from recombinant DNA on the anaemia of patients maintained by chronic haemodialysis. Lancet 1986;ii:1175-8.

3 Eschbach JW, Kelly MR, Haley NR, Abels RI, Adamson JW. Treatment of the anemia of progressive renal failure with recombinant human erythropoietin. $N$ Engl f Med 1989;321:158-63.

4 Bommer J Samtleben W, Koch KM, Baldamus CA, Grützmacher P, Scigall $P$. Variations of recombinant human erythropoietin application in haemodialysis patients. Contrib Nephrol 1989;76:149-58.

5 Machin D, Lewith GT, Wylson S. Pain measurement in randomized clinica trials. A comparison of two pain scales. Clinical foumal of Pain 1988;4:161-8.

(Accepted 27 March 1991) 